\title{
Norveç'te Refah Devletinin Ortaya Çıkışı ve Gelişimi
}

\author{
DOI: $10.26466 /$ opus.501680 \\ * \\ Mahmut Küçükoğlu* $-\underline{\text { Hüseyin Ercan }}{ }^{* *}$ \\ * Dr.Öğr.Üyesi.,Yalova Üniversitesi, İïB, İktisat Bölümü, Yalova/Türkiye/ Türkiye \\ E-Posta: mahmut.kucukoglu@yalova.edu.tr ORCID: $\underline{0000-0002-8286-6929}$ \\ ** Doktorant,Harran Üniversitesi, Maliye ABD, Şanlıurfa/Türkiye \\ E-Posta: huseyin.ercan@inonu.edu.tr \\ ORCID: $\underline{0000-0003-2641-3674}$
}

\section{Öz}

Norveç, genel olarak sosyal devlet anlayışının ve demokrat refah devletinin iyi bir temsilcisi olarak bilinmektedir. Norveç toplumu diğer gelişmiş dünya ülkeleri ile karşılaştırıldığında gelir dağılımındaki adaletsizliğin ve yoksulluk düzeyinin düşük olduğu, üst seviyede sosyal güvenin ve kaliteli yaşam standartlarının oluşturulduğu görülmektedir. Norveç refah devletinin üç tane karakteristik özelliğe sahiptir; birincisi, kapsamlı bir sosyal politika ikincisi, kurumsallaşmış sosyal haklar, üçüncüsü dayanışmacı ve evrensel sosyal yasalardır. Norveç refah devleti modeli ülkede yaşayan tüm vatandaşlara gelir güvenliği ve refah hizmetleri sağlamaktan sorumludur. Evrensel ve cömert bir sosyal güvenlik sistemi bireysel hakları ve yükümlülükleri esas alır. Ĕ̆itim, să̆lık, yaşl ve engelli bakım hizmetleri kamu tarafından ă̆ırlıklı olarak karşılanır. Norveç refah devletinin temel özelliği işgücü piyasası ile refah sisteminin birleştirilmesidir. Refah devletinin yönetimi ve finansmanı merkezi yönetim ile yerel yönetim arasında paylaştırılmıştır. Bu çalışmada, Refah devleti kavramının tanımı ve tarihsel gelişiminden hareketle Norveçörneği ele alınarak, Norveç refah devletinin temel özellikleri ve diğer gelişmiş bazı dünya ülkeleri ile sosyal politikalar ile kamu gelir ve giderleri açısından karşılaştırmalar yapılarak refah devleti olmanın temel unsurları üzerinde durulacaktır.

Anahtar Kelimeler: Norveç, Refah Devleti, Refah Devleti Finansmanı 


\title{
Show Up and Development of The Welfare State in Norway
}

\begin{abstract}
Norway is generally known as a good representative of the social state and the democratic welfare state. When compared with other developed countries in the world, it is seen that the level of injustice and poverty in the income distribution is low, and that high level of social trust and quality of living standards are established. The Norwegian welfare state has three characteristic features, first, a comprehensive social policy, second, institutionalized social rights, the third is solidarity and universal social laws. The Norwegian welfare state model is responsible for providing income security and welfare services to all citizens living in the country. Education, health, elderly and disabled care services are covered by the public. A universal and generous social security system is based on individual rights and obligations. The main feature of the Norwegian welfare state is the unification of the labor market and the welfare system. The management and financing of the welfare state is shared between the central government and the local government. In this study, based on the definition and historical development of the concept of welfare state, the example of Norway will be discussed and the basic features of the Norwegian welfare state and some other developed countries, social policies and public revenues and expenditures will be compared and the basic elements of the welfare state will be discussed.
\end{abstract}

Keywords : Norway, Welfare State, Welfare State Financing 


\section{Giriş}

Norveç çoğu zaman sosyal demokrat refah devleti rejiminin cömert ve evrensel bir örneği olarak tanımlanır. Diğer OECD ülkeleri ile karşılaştırıldığında Norveç, kaliteli iyi bir yaşam, yüksek düzeyde sosyal güven, düşük yoksulluk düzeyi ve düşük gelir dağılımı adaletsizliğine sahip bir ülkedir. Norveç refah devleti tarafından sunulan hizmetler; yüksek istihdam, barış̧̧ıl endüstriyel ilişkiler, yüksek ekonomik büyüme gibi politikalarla desteklenmektedir.

Norveç'in refah devleti olma yolunda yaptığ 1 reformlar $1845^{\prime}$ de ilk yoksulluk yasasının kabul edilmesine kadar gidebilmektedir. Halkın refah devletine yaklaşımı evrensellik, vergi verme, eşitlik ve herkesin sağlık ve sosyal haklara sahip olmasıdır. Her bireyin bir işte çalışma hakkına sahip olmasının yanı sıra her bireyin vergi ödeyerek de ekonomik büyümeye katkı sağlamak gibi sorumlulukları da bulunmaktadır.

İkinci Dünya Savaşı sonrasında verimlilik ilkesi ve sosyal yatırım stratejileri, hasta ve engelliler için sosyal sigorta programları başlatılmasına rağmen sosyal yardım alanında Yoksulluk Yasası geçerliliğini hala korumaktadır.

Norveç yüz yıl önce Avrupa'nın en fakir ülkeleri arsında iken bugün dünyanın en zenginleri arasındadır. Ekonomik ilerleme ve refah açısından başarılı bir performans ortaya koymuştur. Norveç'in refah devleti olmasındaki ön koşulu, yapısal bir sistem için partileri cesaretlendiren yerel kodda yazılan kanun düzeni, mülkiyet hakları, teşvikler, gelenekler olarak ifade etmek mümkündür.

\section{Refah Devleti Tanımı ve Tarihsel Gelişimi}

Refah devleti 18 yy. da sanayi devrimi ile ortaya çıkmıştır. Kapitalizmle ortaya çıkan, insanların düşük ücret karşılığında çok kötü çalışma koşulları altında çalıştırıldıkları bir dönem yaşanmıştır. İşçi sınıfının ortaya çıkması ile birlikte emeğinden başka geçim kaynağı olmayan kişilerin bir tehlike ile karşılaştığında emeğini kullanamaz hale gelmesi durumunda hem kendisinin hem de geçindirmiş olduğu diğer kişilerin yaşamlarını sürdürebilmeleri sıkıntılar yaratmıştır. Bu endüstriyel ilişkiler sınırlı ücretle çalışan emeğin kötü koşullara maruz kalmasıyla bu 
durumdan rahatsız olan kişilerin öncülüğünde bu kötü gidişata çözüm bulmak için çaba göstermesi ve karşılığında devletlerinde yasalar çıkartarak müdahalede bulunduğu görülmüştür. (Özdemir, 2007, s.1).

Modern anlamda refah devletinin ortaya çıkışı dört döneme ayrılabilir. Birinci dönem olarak 1880 'den önceki dönem, devletin paternalist bir yaklaşım göstermiştir. Bu dönemde, sorunların çözümünde aileler, gönüllü kuruluşlar, dini kuruluşlar, hayırseverlik duygularıyla hareket eden kurumlar, bireysel sorumluluk aidiyetine sahip işverenler ve devletin gelir destekleri önemli rol oynamıştır. 1880-1945 yılları ikinci dönem sosyal sigorta dönemidir. Çalışanların zorunlu ödeme yaptıkları sosyal sigorta kurumlarının şemsiyesi altındadır. Üçüncü dönem 1945-1975 yani refahın çağıdır. Bu dönem sosyal sigorta güvencesi yanında refah devletinin fonksiyon ve kurumlarının genişlemesi, gelirin sürekli olmasının sağlanması ve yaşam standartlarının yükseltilmesinin olduğu bir dönemdir. Son dönem ise 1975 sonrasıdır. Refah devleti anlayışının krize girdiği ve refah anlayışının yeniden yapılanmaya başladığı dönemdir. (Özdemir, 2007, s.177-178).

Literatürde refah devleti için birçok tanım kullanılmaktadır. Günümüzde kullanılan refah devleti tanımı, sosyal refahın maksimizasyonu amaciyla ekonomiye aktif ve kapsamlı müdahalelerde bulunmasını meşru kılan bir devlet anlayışıdır. Refah devleti, ekonomideki piyasa başarısızlıklarının ve yetersizliklerinin ortadan kaldırılması amacıyla müdahaleci, düzenleyici, yeniden dağıtıcı ve girişimci bir devlet anlayışına denir. (Yıldırım, 2014, s.1).

Briggs'e göre, refah devleti, üç alanda aktif durumdadır: Birincisi, bireylere ve ailelere, minimum düzeyde gelir garantisi sağlamaktadır. İkincisi, vatandaşlara, belirli sosyal risklerin (hastalık, yaşlılık, işsizlik vb.) üstesinden gelmelerinde yardımcı olmaktadır. Üçüncüsü ise, sosyal refah hizmetleri vasıtasıyla tüm vatandaşlara en iyi yaşam standartlarını sağlamaktır. (Briggs, 1961, s.16).

Refah devleti kavramı ülkelerde anlayış bakımından farklı anlamlarda kullanılmaktadır. İsveç'te ve diğer İskandinav ülkelerinde refah devletinin en çarpıcı özelliği; vatandaşların hepsine çalışma hakkının devlet tarafından garanti edilmesidir. Almanya' da sosyal refah devletinin özelliği ise sosyal güvenlik hakkının devlet tarafından sağlanmasıdır. Devlet ayrıca gelir dağılımını sağlamada da aktif rol üstlenmiştir. ABD ve 
İngiltere'de ise sosyal refah devleti anlayışı diğer ülkelere göre farklıdır. $\mathrm{Bu}$ ülkelerde devlet vatandaşa ancak zor durumda ise geçici nitelikte yardım eder. ABD'de yalnızca devlet kaynaklı emeklilik sistemi varken; İngiltere'de, sosyal güvenlik, sağlık, eğitim gibi önemli harcama kalemlerinin yanında sığınma evleri gibi küçük faydaları da içine alan bir sistem söz konusudur (Erdal, 2012, s.22).

II. Dünya Savaşı sonrası dönemde uygulanma imkânı bulan refah devleti, kişilere ve ailelere asgari bir gelir güvencesi veren, onları toplumsal tehlikelere karşı koruyan, onlara sosyal güvenlik olanakları sağlayan, toplumsal konumları ne olursa olsun tüm vatandaşlarına eğitim, sağllk, konut gibi sosyal alanda hizmetlere bir standart getiren devlettir(Akkaya, 2001, s.26).

Benzer özellik gösteren refah devleti bir grup altında toplamak bir sınıflandırmaya tabi tutmak için birçok çalışma yapılmıştır. Bunun sebebi de uygulamada farklı şekillerde refah devleti ortaya çıkmasıdır. Refah anlayışı, neredeyse her bir ülkede farklı yapıdadır. Ulus devletlerin ekonomik, kültürel ve tarihsel geleneklere göre farklı yapıda refah devletleri ortaya çıkmıştır. Yapılan sınıflandırma çalışmalarında gelişmiş ülkeler, refah anlayışı açısından belirli nitelik ve kriterlere göre sınıflandırma yapılmış farklı refah devleti kategorilerine ayrılmıştır. Ayrıca hiçbir ülke tam anlamıyla bir kategoriye uygun düşmemektedir. Çünkü ülkelerin sosyal ve ekonomik yapısı zamanla bir tür içerisinde yer almamaktadır. Refah devleti sınıflandırmasına ilişkin çok sayıda değişik kriter dikkate alınmaya başlanmıştır. Yazarlar tarafından en çok kabul edilen sınıflandırma Esping- Andersen tarafından yapılan çalışmadır. Bu tasnife göre, üç tür refah rejimi sınıflandırması yapmıştır. Liberal refah modeli (ABD, Avustralya, İngiltere), Kita Avrupası Refah Modeli (Fransa, Belçika, Almanya) ve İskandinav Refah Modeli (İsveç, Danimarka) şeklindedir (Özdemir, 2007, s.155-156).

\section{Norveç Refah Devletinin Ortaya Çıkışı ve Tarihsel Gelişimi}

1814'de Danimarka Norveç kolonisini kaybetmiş, İsveç'le özerk bir birlik oluşturulmuştur. Norveç o dönemde yaygın çiftçi mal sahipliği olan aristokrasinin olmadığ 1 küçük bir ekonomiye sahip olarak, iktidardaki gruplar, devlet bürokratları, küçük fakat artan burjuvazi, birkaç zengin çiftçi 
şeklinde politik olarak bölünmüştür.Bürokratlar çiftçileri sadık müşteri olarak görmelerine karşın mal sahibi ve kiracılara oy hakkı tanıan bir anayasa istemişler ve 1814 Anayasası bir politik sistem yaratmıştır. 19. yüzyılda ana endüstriler ormancılık, madencilik, balıkçılık ve gemi yapımıdır. 1880'lerde ise Norveç dünyanın en büyük üçüncü ticaret filosu olmuştur (Fagerberg ve Cappelen, 1990, s.61-62).

Sosyal Refahla ilgili meseleler 1880 'ler boyunca problem olarak ortaya çıkmıştır. Bu durum yoksullara yapılan yardımların memnuniyetsizliğinin bir sonucu olarak ortaya çımıştır. Norveç'de kamu yardımlarının ilk yasal şekli 1845' de daha sonra bu kanun 1863 yılında ve 1900 yılında değiştirilmiştir. 1964 yılına kadar bu yasa kullanılmıştır. Daha sonra Sosyal Bakım Yasası geçirilerek kendi kendine yetebilme ve yasa ile karı koca ile ebeveyn çocuk arasında karşılıklı destek ilkesini amaçlanmıştır. Bu temel destek sisteminin çökmesi durumunda kamu desteğine başvurulmaktadır. 1863 yasa değişikliğine kadar öksüz olan ve akıl hastası olan kişilere yardım yapılırken diğer gruplar için kendi kendine yetebilme ilkesi benimsenmiş aile ve akraba desteği kabul edilmiştir. Muhtaç olanların çoğunu aile desteği olmayan kadın ve çocuklar oluşturmaktadır. 1885 yılında Liberal hükümet sosyal sorunları tüm yönleriyle araştırması için bir komite görevlendirmiş, Norveç'de sosyal sorunların büyük ölçüde fabrika iş̧̧ileriyle alakalı olduğunun farkına varılmıştır. 1892 yılında Fabrika Denetim Yasası kabul edilerek kazalarını önlemek ve işyerlerinin hijyenliğini artırmak amaçlanmıştır. 1894 yılında Kaza Sigorta Yasası ve 1909 yılında Hastalık Sigortası Yasası kabul edilerek işçilerin kaza ve hastalık durumunda gelir kaybını telafi etmek amaçlanmıştır(Bjørnson, 2001, s.199-200).

Norveç'in refah devletialanında yapılan yeniliklerden ilki $1845^{\prime}$ de çıkarılan yoksulluk yasasıyla başlamaktadır. Kuzey Avrupa Refah Devleti Modeli kurumsal geri dönüşümlü refah modeli söz konusudur. Halkın refah devletine bakışı, evrensellik, vergi verme, eşitlik ve herkesin sağlık ve sosyal haklara sahip olmasıdır. Norveç ve diğer İskandinav ülkeleri genellikle "işçi toplumu" veya İskandinav modeli iş rejimi olarak bilinmektedir. Bu modelin en önemli özelliği herkese iş ve tam ücret politikasıdır. 1954 Norveç Anayasasıhükümeteen önemli görev olarak yeni istihdam alanları yaratmayı vermiştir. "Herkese iş" anlayışının benimsendiği Norveç refah devleti; sosyal adalet, sosyal güvenlik, birlik ve yardımlaşma 
ve katılımı ilke edinmiştir. Sağlam iş ahlakı ve tam istihdamın sağlanması refahınartmasına, eşitsizliğin, yoksulluğun ve bağımlılığın azaltılmasını, bireylerin özgüvenin yükselmesine ve topluma güvenli katılımı kolaylaştırmaktadır. Her vatandaşın çalışma hakkının yanı sıra vergivererek ekonomik büyümeye destek olmak gibi sorumluluğu da vardır. II. Dünya savaşı sonrası yıllarda çalışma gücüne sahip her erkeğin kendi bağımsızlığını alması gerekliydi ve kadınlar eşleri tarafından desteklenmekteydi. Günümüzde ise her çalışma gücüne sahip kişilerin bağımsız ve özerk olması hedeflenmektedir. "Herkese iş" sağlanması genel amacı oluşturmaktadır. Ülkenin refah politikasının temel amacı, kişisel özgürlük ve özerklik, fırsat eşitliği, sosyal adalet, sosyal eşitlik, bireylerin mutluluğu ve kimlik oluşumu, sosyal birlik ve dayanışma gibi kavramlar oluşturmaktadır (Gülaldı, 2009, s.4-5).

Gelişmiş kapitalist ülkelerde II. Dünya Savaşı sonrası uygulanan refah devleti modelleri içerisinde Kuzey Avrupa modeli, ücretlerin pazarlık sonucunda belirlendiği, kadın işgücü katılım oranının yüksek olduğu, vergi tabanının geniş olduğu, kamu hizmetleri alanının geniş olması, kamu istihdam oranının yüksek olması, eğitim sevisinin yüksek olması bu devletleri diğer refah devleti modellerinden farklılık arz etmektedir. Refah devleti ile piyasa ekonomisini birleştiren bu model anlayışı kalkınma, gelişmişlik, hayat standardı, demokrasi, toplumsal eşitlik, cinsiyet eşitliği gibi iktisadi politik göstergeleri açısından dünya ülkeleri arasında ön sıralarda performans göstermişlerdir. OECD verilerine göre Gini katsayısı gelir dağılımı sıralamasında ilk dört ülkenin dördünün de Kuzey Avrupa ülkesi olması tesadüf değildir. Kuzey Avrupa ülkelerinin bir başka ayırt edici özelliği de güçlü devlet anlayışının yanı sıra, bir tarafta güçlü bir kamu maliyesinin varlığı ve diğer tarafta ise güçlü/bağımsız bireyin refah devleti modelinin temel amacını oluşturmasıdır; devletin refah işlevi bireyin güçlendirmesi ön plandadır. Bireylerin kendi kapasitelerini yükseltmesini ve toplumsal eşitliği sağlamaya yönelik yükselmelerine imkan sunan mekanizmalar oluşturmaktadır (Karahanoğulları, 2013, s.234).

Savaş sonrası dönemde Norveç'in en önemli amaçlarından birisi, herkes için iş sağlamaktır. Sosyal sigorta, kentsel refah ve aile politikaları Norveç refah devletinin en önemli özelliklerini oluşturur (Bjørnson, 2001, s.199-200). 
Norveç'in kalkınmasında rol alan iki önemli tarihsel dönüm noktası olmuştur. Bunlardan birincisi Büyük Buhran'ın yarattığı ve ikincisi ise II.Dünya Savaşını yaratmış olduğu tahribatı ortadan kaldırmak için oluşturulan toplumsal mutabakattır. Her iki dönüm noktasında Norveç ulusal kalkınma amacıyla işçi ve işveren sendikalarının üzerinde anlaştıkları bir sosyoekonomik programları uygulamışlardır.

Savaş sonrası Norveç ekonomi politikaları 1930'lu yıllardaki uluslararası resesyon boyunca Keynes tarafından ileri sürülen teoriler rehber alınmıştır. Bundan işsizliği azaltmak için, ekonominin talep yanlı kamu politikaları uygulanması kastedilir. II. Dünya Savaşından sonraki ilk on yl boyunca verimlilik ilkeleri ve sosyal yatırım stratejileri hasta ve özürlüler için sosyal güvenlik programlarını temel aldılar (Dahl vd. 2001, s.301).

Nazi işgalinin kurtuluşu sonrası 1945 yılında “Ulusal Kurtuluş Programı" tüm siyasi partilerin desteğiyle geniş bir siyasal birlik içerisinde hazırlanmış ve uygulamaya geçilmiştir. Norveç II. Dünya Savaşı sonrasında kapitalist sistem içerisinde kalarak geliştirdiği eşitlikçi, sosyal devlet modelinin temelleri istikrarlı ve güçlü ekonomik büyüme, dış ticaret dengesinin sağlanması, tam istihdam fiyat istikrarı ve gelir dağılımında eşitlik hedefleri çerçevesinde atılabilmiştir (Fagerberg vd. 1990: 64). Savaş sonrası Norveç'in sosyal politika ve programlarına baktığımızda ilk olarak kamu belgelerinden yararlandığımızda; ilki devlet politikalarında hastaları ve özürlüleri hedef almakta, ikinci olarak, devlet tarafından aktif işgücü piyasasına yönelik politikaları yaygınlaştırmak, üçüncüsü sosyal hizmetler ve sosyal yardım programları üzerine yerel seviyede organize etmek ve finanse etmek (Dahl vd. 2001, s.301).

Ekonomik büyüme ve tam istihdam 1945-1965 yılları arasında İşçi Partisi hükümetlerinin temel amaçları arasındadır. Bu her iki amaç da temel sosyal reformların yerine getirilmesinde ön koşul olarak görülmektedir. 1945-1980 arası sosyal politika reformları şu şekilde sayılabilir; 1940'larda ve 1950'li yılların başlarında hükümetlerin gündeminde ilk sırada ekonomik büyüme daha sonra bunun dağıtımı yer almaktaydı. 1946 yılında Evrensel Çocuk Yardım Planı, 1949 yılında Tarım işçileri İşsizlik Sigortası Sistemine dahil edildi, 1953 tim çalışanlara zorunlu hastalık sigortası uygulaması kabul edildi, 1956 yılında tüm yerleşiklere hastalık sigortası uygulandı, 1957 yılında yaşlı emekli maaş sisteminde gelir 
testi usulu kaldırıldı, 1957 yılında yetimlere maaş uygulaması başlatıldı, 1958 evrensel iş kazası sigorta sistemi, 1961 yılında malulluk aylığı sistemi başlatıldı, 1964 yılında Dul ve bekar annelere aylık, 1966 yılında Ulusal Sigorta Sitemine yaşlılar, yetimler, dul ve bekar annelerde dahil edildi, 1970 yılında ilk çocuklar içinde yardım başlatıldı, 1971 yılında hastalık ve sağlık sigortaları ile iş kaza sigortası ve işsizlik sigortası Ulusal Sigorta Sistemi kapsamına alınmıştır, 1978 yılında hastalık durumunda \%100 ücret ödenmesi, 1973 yılında resmi emeklilik yaşı 70'den 67'ye düşürülmüştür. Sakatlık ödeme kriterleri genişletildi. 1978 yılında hastalık ödeneği başlatıldı. Çoğu yazar 1945-1980 yılları arasında Norveç refah devletinin genişlemesini geniş siyasal çevrelerce kabul görmesidir (Sørvoll, 2015, s.4).

Tablo 1. Nordik ülkelerde Çeşitli Sigortaların Başlangıç Tarihleri

\begin{tabular}{|c|c|c|c|c|}
\hline Sistem & Danimarka & Finlandiya & Norveç & İsveç \\
\hline Endüstriyel & 1898 & 1895 & 1894 & 1901 \\
\hline Kaza Sigortası & 1916 & 1917 & $\begin{array}{l}1901 \\
1921 \\
\end{array}$ & 1916 \\
\hline $\begin{array}{l}\text { Ulusal } \\
\text { Hastalık } \\
\text { Sigortası }\end{array}$ & 1933 & 1963 & $\begin{array}{l}1909 \\
1953\end{array}$ & 1955 \\
\hline $\begin{array}{l}\text { Ulusal Emekli } \\
\text { Maaş } \\
\text { Uygulaması }\end{array}$ & $\begin{array}{l}1891 \\
1922 \\
1933 \\
\end{array}$ & 1937 & 1936 & 1913 \\
\hline $\begin{array}{l}\text { İşsizlik } \\
\text { Sigortası }\end{array}$ & - & - & 1938 & - \\
\hline Çocuk Yardımı & 1952 & 1948 & 1946 & 1948 \\
\hline
\end{tabular}

Kaynak: Alestalo, Hort, ve Kuhnle,13.

Yukarıdaki tablo incelendiğinde refah devleti uygulamalarının Nordik ülkeler arasında birçok alanda Norveç'in öncü olduğu görülmektedir.

\section{Norveç Refah Devletinin Temel Özellikleri}

Norveç refah devleti modeli ülkede yaşayan tüm vatandaşlara gelir güvenliği ve refah hizmetleri sağlamaktan sorumludur. Evrensel ve cömert bir sosyal güvenlik sistemi bireysel hakları ve yükümlülükleri esas alır. Eğitim, sağlık, yaşlı ve engelli bakım hizmetleri kamu tarafından 
ağırlıklı olarak karşılanır. Aktif işgücü piyasa politikaları (iş yaklaşımlı politikalar) işgücünün yüksek oranda katılımını amaçlar. Hiç geliri olmayan ya da düşük gelire sahip bireylere yardım amaçlı yüksek kamu harcamaları yapılması, devletle iyi organize olmuş diğer sosyal gruplar arasında ulusal seviyedeki işbirliği, özellikle istihdam, sosyal dağıtım, yaşam ve çalışma şartları ile ilgili kararlarda işverenle çalışan arasındaki çok boyutlu uzlaşmanın olması esastır. Bu sistemin esas özelliği, işgücü piyasası ile refah sistemi arasındaki etkileşimdir ve bunlar tamamlayıcı sistemlerdir (Schafft, 2009, s.1-2).

Norveç refah devletinin temel özelliği işgücü piyasası ile refah sisteminin birleştirilmesidir. Refah devletinin yönetimi ve finansmanı merkezi yönetim ile yerel yönetim arasında paylaştırılmıştır. Merkezi yönetim genel işgücü piyasası ile ilgili politikalar ve istihdama duyarlı grupları belirlemede yetkilidir. Ayrıca sosyal sigorta ve çeşitli aile yardımlarından da sorumludur. Norveç refah politikalarında iş yaklaşımc modeli benimsenmiştir. Norveç son yıllarda diğer İskandinav ülkelerinde olduğu gibi makro ekonomik performansı ve yüksek istihdamı sosyal adalet ile birleştirmiştir. (Schafft, 2009, s. 1).

Norveç çoğu zaman cömert ve evrensel sosyal demokrat refah devleti rejiminin bir örneği olarak tasvir edilir. Diğer OECD ülkeleriyle karşılaştırıldığında yüksek kaliteli yaşam, yüksek sosyal güven, düşük yoksulluk oranı ve düşük ekonomik eşitsizlik Norveç toplumunun temel özellikleridir. Kapsamlı bir Norveç refah hizmetleri; yüksek istihdam, barışçıl endüstriyel ilişkiler ve ekonomik büyümenin artırılması için uygulanacak politikalara zemin hazırlamaktadır (Sørvoll, 2015, s.1).

Norveç refah devletinin üç tane karakteristik özelliğe sahiptir; birincisi, kapsamlı bir sosyal politika ikincisi, kurumsallaşmış sosyal haklar, üçüncüsü dayanışmacı ve evrensel sosyal yasalardır. Norveç refah devletinde refahla ilgili kamu harcamalarının yüksek olması, işgücüne katılımım yüksek olması özellikle kadınlarda, düşük işsizlik oranın olması, yüksek ekonomik büyümenin olması bunların hepsinin birleşiminden oluşmaktadır. (Stamsø, 2009, s.200).

Nordik modelin temel özelliği, aktif sosyal ve ekonomik politikaların kombinasyonundan oluşmaktadır. Ücretsiz eğitim, çalışma çağındaki nüfusa iş imkanı sağlanması, kapsamlı bir sosyal koruma sistemi oluştu- 
rulması halinde bireylere yaşam fırsatlarının eşitlenmesini destekler. Nordik refah modeli, rekabet ve verimliliğe yönelten ekonomik ve endüstriyel politikaların birleşiminden oluşmaktadır (Sørvoll, 2015, s.1).

Güçlü işgücü hareketlerini karşılamak için siyasi çözümler uygulanarak haklar verilmiş, güvenlik garanti altına alınmış ve oy kullanma tüm yetişkinlere tanınmıştır. İç çekişmeden sakınmak için işçi ve işveren arasında işbirliği vardır. Kollektif hareket etmek için insanları cesaretlendirecek kuruluşlar ortaya çıkmış özellikle yüzyılın ikinci yarısında çok az sayıda grev olmuştur. Norveç birikmiş çabaların gücüyle çalışmaya başlamış ve yavaş bir şekilde fakat emin adımlarla modern üretim metodları el emeği yerine geçmiştir. Eğitimde yatırımlar yapılmış veyaygın eğitim artmıştır. Okullar, kolejler ve üniversiteler çoğalmış,beşeri sermaye artmıştır.Fiziksel sermayeyi hızlandırmak için yatırımlara yönelinerek makinalar edinilmiş, elektrik üretilmiş bu sayede işgücünün birim başına üretiminde artış meydana gelmiştir.

Norveç teknik ilerlemeyi yakalamak için ithalata başvurmuş var olan bilgiden faydalanmıştır.

Norveç kalkınmasının temelini verimlilik oluşturur. Bazı ülkeler büyüme ve verimlilikte patlama yaşarken Norveç istikrarlı bir şekilde büyümüştür.

Kapsamlı Norveç refah hizmetleri ile yüksek istihdam, barışçıl endüstriyel ilişkiler ve ekonomik büyümeyi teşvik etmeye dönük politikalar desteklenmektedir. Norveç modelinin temel özelliği aktif sosyal ve ekonomik politikaların birleşiminden oluşmaktadır. Rekabet ve verimlilik esaslı ekonomik ve endüstriyel politikaların bileşimidir (Sørvoll, 2015, s.1).

\section{Norveç'in Genel Özellikleri}

İskandinavya Yarımadasının kuzeyini ve batısını oluşturan, Batı Avrupa'nın en kuzey bölgesinde yer alan bir bağımsız krallıktır. Yüzölçümü $323.878 \mathrm{~km}^{2}$ dir. Norveç, bir zamanlar Avrupa'nın en fakir ülkelerinden biriyken, etrafını çeviren sulardan elde ettiği petrol ve doğal gaz sayesinde, dünyanın en zengin ülkelerinden biri haline gelmiştir (Özey, 2009, s.168). Norveç 2014 y1lı verilerine göre 5.1 milyonluk bir nüfusa sahiptir (OECD, Erişim Tarihi: 07.11.2017). 
Norveç yüzölçümü açısından büyük, nüfus açısından küçük bir ülkedir. Norveç'de kamu idaresi, üç bölümden oluşmaktadır, bunlar merkezi yönetim, il yönetimi ve belediyelerdir. Yerel yönetimler 18 il yönetimi ve 428 belediyeden oluşmaktadır. Yerel idarelerin gelirleri vergiler ve merkezi idarenin aktarmış olduğu yardımlardan oluşmaktadır. Diğer Nordik ülkeler gibi Norveç'de de refah hizmetlerinin önemli bir kısmı yerel idareler tarafından sağlanmaktadır. Yerel idareler kamu tüketiminin neredeyse yarısını ve GSYH'nın neredeyse \%20'sini oluşturmaktadır. İşgücünün \%20'sini istihdam etmektedir (Borge, 2016, s.3). Norveç merkez hükümetinin görevleri; ulusal sigorta hizmetleri, üniversite eğitimi, hastaneler, işgücü piyasa, mülteci ve göçmenler, tarımsal konular, çevresel sorunlar, polis, mahkemeler, ordu, diş politika konuları (Local Government in Norway, 2014, s. 10).

Norveç, son yıllarda hızlı bir değişim geçirmektedir. Nüfus yapısı, yaşam koşulları ve yerleşim düzeni değişmiştir. 1970 sonrası petrol ve doğal gaz rezervlerinin bulunması ve balıkçılık sektörünün yarattı̆̆ katma değerle birleşince ekonomisi hızla gelişme göstermiştir. Norveç'in yaşam standartları açısından diğer Avrupa Birliği ülkelerinden yüksek olması Norveç'in Avrupa Birliği'ne üye olarak katılmasına ihtiyaç duymamıştır (Çiçek ve Çiçek, 2012, s. 202).

Norveç serbest piyasa ekonomisi ve devlet müdahalesinden birleşiminden doğan karma bir ekonomidir. Devlet, petrol sektörü, elektrik üretimi gibi kilit alanları kontrol eder (Tatari, 2006, s.3).

Norveç refah devleti sistemini üç ana ilke üzerine kurmuştur. Birinci ilke, Norveç'de yaşayan her vatandaş sosyal refah programlarına erişim hakkına sahiptir. İkinci ilke, her vatandaşın geliri ile doğru orantılı olarak hizmetten yararlanmalıdır. Son ilke ise, tüm sosyal hizmetler özel kişi ve kurumlar yerine kamu tarafından sunulmalıdır (Fouberg ve Hogan, 2004, s.63).

Toplam harcamaların içerisinde en fazla pay sosyal koruma hizmetlerine verilmiştir. 2000 yılında toplam harcamaların \%37'sini sosyal koruma hizmetleri oluştur iken 2013 yllında \%40 yükselmiştir. Sosyal koruma hizmetleri içerisinde ise en fazla harcama; hastalık ve engellilik hali, emeklilik, aile ve çocuklara yönelik hizmetlerden oluşmaktadır (Dikmen, 196). 
Norveç Refah sistemi olarak Ulusal sigorta uygulaması, sosyal hizmet uygulaması, hastane, rehabilitasyon enstitüleri, sağlık enstitüleri, çalışma politikaları, üniversite seviyesine kadar ücretsiz eğitim, evde bakım hizmetleri, profesyonel yardımlar şeklindedir (Albayrak ve Birinci, 2017, s.74).

Son on yıldır Norveç refah politikalarında iş yaklaşımcı anlayışı benimsemektedir. Çalışma yaşındaki kişilere yapılan sosyal yardım ve sosyal güvenlik ödemelerinde pasif destek ödemeleri alan kişileri işgücü piyasasıyla bağlantı kurmaktadır. Hassas gruplardaki yoksulluğu azaltmak için de hükümetin amacı bu grupları işgücü piyasası dahil etmektir.

Tablo 2. Norveç'e Ait Çeşitli Sosyo-Ekonomik Göstergeler

\begin{tabular}{lllllll}
\hline YILLAR & $\mathbf{1 9 7 0}$ & $\mathbf{1 9 8 0}$ & $\mathbf{1 9 9 0}$ & $\mathbf{2 0 0 0}$ & $\mathbf{2 0 1 0}$ & $\mathbf{2 0 1 6}$ \\
\hline Nüfus (milyon) & 3.879 & 4.086 & 4.241 & 4.491 & 4.889 & 5.232 \\
\hline $\begin{array}{l}\text { Doğurganlık } \\
\text { Oranı }\end{array}$ & 2,5 & 1,7 & 1,9 & 1,9 & 1,9 & $1,7(2015)$ \\
\hline $\begin{array}{l}\text { GSYH(Milyar } \\
\text { Doları) }\end{array}$ & 12.814 & 64.439 & 119.792 & 171.316 & 429.131 & 371.076 \\
\hline $\begin{array}{l}\text { Kişi Başına } \\
\begin{array}{l}\text { GSYH(ABD } \\
\text { Doları) }\end{array}\end{array}$ & 3.368 & 9.870 & 18.444 & 36.950 & 58.025 & 58.792 \\
\hline $\begin{array}{l}\text { Ekonomik } \\
\text { Büyüme }\end{array}$ & 1,9 & 4,5 & 1,9 & 3,2 & 0,6 & 1,0 \\
\hline $\begin{array}{l}\text { Isssizlik Oranı } \\
\text { Enflasyon Oranı }\end{array}$ & 0,8 & 1,6 & 5,3 & 3,5 & 3,5 & 4,7 \\
\hline
\end{tabular}

Kaynak: $\quad$ https://data.worldbank.org/indicator/SP.DYN.TFRT.IN?locations=NO https://data.oecd.org. (Erişim Tarihi: 11.01.2018).

Tablo 3. Norveç'in GSYH'ın Sektörel Dağılımı

\begin{tabular}{lllllll}
\hline YILLAR & $\mathbf{1 9 7 0}$ & $\mathbf{1 9 8 0}$ & $\mathbf{1 9 9 0}$ & $\mathbf{2 0 0 0}$ & $\mathbf{2 0 1 0}$ & $\mathbf{2 0 1 6}$ \\
\hline Tarim & 5,8 & 4,0 & 3,3 & 2,0 & 1,7 & 2,4 \\
\hline Sanayi & 30,78 & 38,21 & 33,22 & 41,37 & 39,00 & 31,96 \\
\hline $\begin{array}{l}\text { Hiz- } \\
\text { metler }\end{array}$ & 63,37 & 57,72 & 63,41 & 56,55 & 59,23 & 65,62 \\
\hline
\end{tabular}

Kaynak:https://data.worldbank.org/indicator/NV.IND.TOTL.ZS?locations=NO (Erişim Tarihi: 11.01.2018). 
Tablo 4. Norveç ve OECD Ülkelerinin Ortalaması Kamu Harcamalarının Fonksiyonlarına Göre Dă̆ılımı (2015)

\begin{tabular}{lcc}
\hline $\begin{array}{l}\text { KAMU HARCAMA } \\
\text { ÇEŞITLERI }\end{array}$ & NORVEÇ & OECD \\
\hline Genel Kamu Hizmetleri & 9,6 & 13,2 \\
\hline Savunma Hizmetleri & 3,1 & 5,1 \\
\hline Kamu Düzeni Ve Güvenliği Hizmetleri & 2,2 & 4,3 \\
\hline Ekonomik Konularla Ilgili Hizmetler & 10,5 & 9,3 \\
\hline Çevre Koruma Hizmetleri & 1,8 & 1,3 \\
\hline Konut Ve Topluma Yönelik Hizmetler & 1,5 & 1,4 \\
\hline Sağllk Hizmetleri & 17,2 & 18,7 \\
\hline Eğlence Kültür Ve Dini Hizmetler & 3,0 & 1,5 \\
\hline Eğitim Hizmetleri & 11,2 & 12,6 \\
\hline Sosyal Koruma Hizmetleri & 39,8 & 32,6
\end{tabular}

Kaynak: OECD National Accounts Statistics (database) http://www.oecd-ilibrary.org/docserver/download/4217001e.pdf?expires $=1515494763$ Eid $=i d$ Eaccname $=$ guestEchecksum $=5$ F80809E68F9329F14A6B6B51853F364 (Erişim Tarihi: 09.01.2018).

Kamu harcamalarının fonksiyonlarına göre dağılımında en yüksek payı sosyal koruma harcamaları almaktadır. Refah devletinin amaçlarından biriside yaşlanma, işsizlik ve hastalık gibi riskleri dağıtmaktır. Sosyal harcamalar içerisinde en yüksek artış sosyal koruma harcamalarında olmuştur.

Tablo 5. Norveç ve OECD Ortalaması Sosyal Koruma Harcamalarının Fonksiyonel Dă̆ılımı (2015)

\begin{tabular}{lcc}
\hline Harcama Çeşitleri & Norveç & OECD \\
\hline Hastalık ve sakatlık & 34,5 & 14,7 \\
\hline Yaşlılık & 36,0 & 53,5 \\
\hline Hayatta Kalanlar & 1,0 & 7,5 \\
\hline Aile ve Çocuk & 18,2 & 9,0 \\
\hline İşsizlik & 2,6 & 7,0 \\
\hline Konut & 0,6 & 2,6 \\
\hline Sosyal Dişlanma & 4,5 & 4,1 \\
\hline Sosyal Koruma & 2,4 & 1,6 \\
\hline Kayna
\end{tabular}

Kaynak: OECD National Accounts Statistics (database) http://www.oecd-ilibrary.org/docserver/download/4217001e.pdf?expires=1515494763Eid=id\&accname=guest\&checksum=5F80809E68F9329F14A6B6B51853F364 (Erişim Tarihi: 09.01.2018). 
Tablo 6. Norveç ve Bazı Ülkelerde Sosyal Harcamaların GSYH'ya Oranı

\begin{tabular}{lllll}
\hline Yillar & $\mathbf{1 9 9 0}$ & $\mathbf{2 0 0 0}$ & $\mathbf{2 0 1 0}$ & $\mathbf{2 0 1 6}$ \\
\hline Almanya & 21,4 & 25,4 & 25,9 & 25,3 \\
\hline Norveç & 21,6 & 20,4 & 21,9 & 25,1 \\
\hline İtalya & 20,7 & 22,6 & 27,6 & 28,9 \\
\hline ABD & 13,2 & 14,3 & 19,3 & 19,3 \\
\hline Türkiye & 5,5 & 7,7 & 12,8 & $13,5(2014)$ \\
\hline OECD & 16,92 & 17,98 & 21,06 & 21,03
\end{tabular}

Kaynak: http://www.oecd.org/social/expenditure.htm (Erişim Tarihi:03.01.2018)

Grafik 1. Norveç ve OECD Ortalaması Sosyal Harcamalar

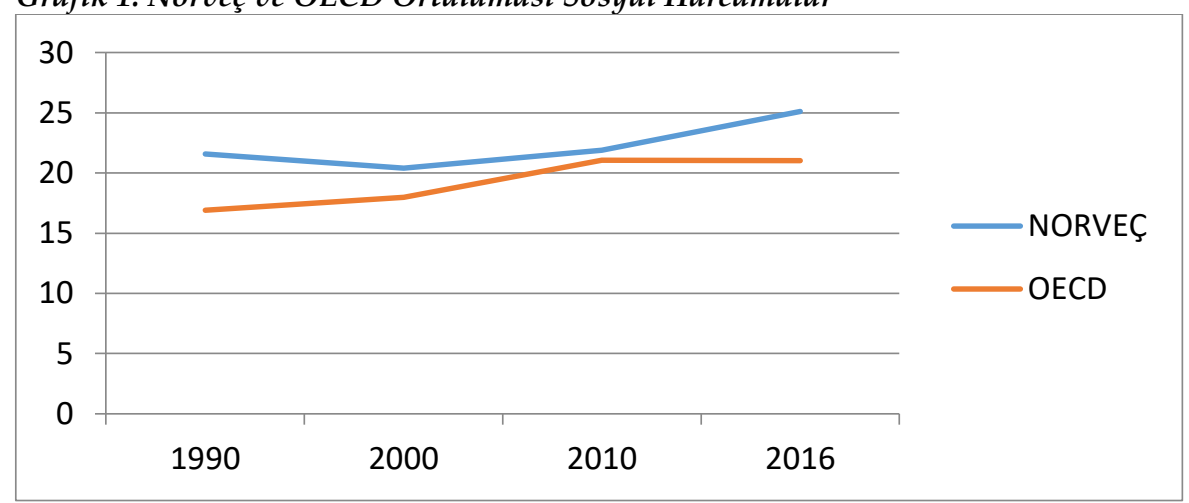

Kaynak: Tarafımızca hazırlanmıştır.

Kamu sosyal harcamaların GSYH'ya oranına baktığımızda yıllar itibariyle \%20'lerde iken, 2016 yılında \%25'e yükselmiştir. OECD ülkelerinin çoğunda sosyal harcamaların GSYH'ya oranı \%21'lerdedir Norveç OECD ortalamasının üzerindedir. Sosyal harcamaların içeriğine baktığımızda en yüksek oran yaşlılara ödenen emekli maaş ödemeleri oluşturmaktadır. İkinci sırada yer alan sağlıkla ilgili transfer harcamaları oluşturmaktadır. Kamu sosyal harcamalarının \%60'ını kamu emekli maaş ödemeleri ile sağlık bakım harcamaları oluşturmaktadır. Sosyal harcamaların GSYH'ya oranı en yüksek olan ülke \%31,5 ile Fransa birinci sırada yer almaktadır. İkinci sırada ise 30,8 ile Finlandiya yer almaktadır. GSYİH'nın \%8'ini yaşlı emekli maaş ödemeleri ile hayatta kalanlara ödenen maaş ödemeleri oluşturmaktadır. İkinci sırada yer alan sağlıkla ilgili sosyal harcamaların oranında da artış olmuştur. Bu artış nedenleri yaşlı nüfusun artması, 
sağlık bakım maliyetlerinin yükselmesi gösterilebilir. Diğer sosyal harcama kalemleri daha düşük düzeydedir. Aile ile ilgili yardım ödemeleri ve iş göremezlik ödemeler GSYH'nın \%6,71'ini oluşturmaktadır. İşgücü piyasasına yönelik politikalar için yapılan ödemeler GSYH'nın \%0,84'dür. Konut ve diğer sosyal harcamalar ise GSYH'nın \%0,79'unu oluşturmaktadir.

Grafik 2. Norveç'de Kamu Sosyal Harcamalarını Amaçlarına Göre GSYH'ya Göre \% (2013)

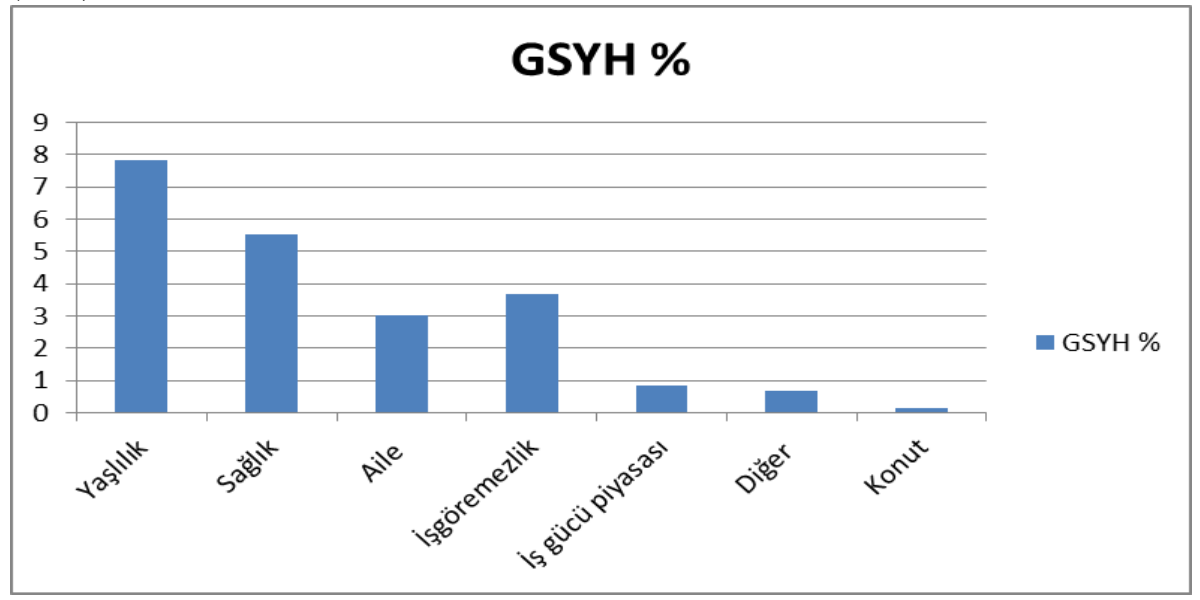

Tablo 7. Norveç'de Sosyal Harcamalarn Yıllara Göre Gelişim Seyri (\% GSYH)

\begin{tabular}{|c|c|c|c|c|c|}
\hline Yillar & 1990 & 2000 & 2005 & 2010 & 2013 \\
\hline Yaşlılık Emekli Maaş Ödemeleri & 6,97 & 6,41 & 6,20 & 6,84 & 7,59 \\
\hline Sağlıkla İlgili ödemeler & 3,87 & 4,33 & 5,14 & 5,59 & 5,54 \\
\hline Aile İle İlgili Ödemeler & 2,68 & 2,99 & 2,79 & 3,07 & 3,02 \\
\hline İşsizlikle İlgili ödemeler & 1,04 & 0,44 & 0,52 & 0,48 & 0,34 \\
\hline $\begin{array}{l}\text { Hayatta Kalanlara Yapılan öd- } \\
\text { emeler }\end{array}$ & 0,43 & 0,29 & 0,29 & 0,28 & 0,25 \\
\hline İş Görmezlikle İlgili ödemeler & 4,62 & 4,56 & 4,30 & 4,17 & 3,69 \\
\hline $\begin{array}{l}\text { Aktif İşgücü Piyasalarına Yönelik } \\
\text { Ödemeler }\end{array}$ & 0,87 & 0,59 & 0,72 & 0,62 & 0,50 \\
\hline $\begin{array}{l}\text { Konut Yardım Ve Kira Süb- } \\
\text { vansiyonları }\end{array}$ & 0,15 & 0,16 & 0,14 & 0,14 & 0,12 \\
\hline Diğer ödemeler & 0,88 & 0,60 & 0,57 & 0,68 & 0,67 \\
\hline
\end{tabular}

Kaynak: http://www.oecd.org/sociallexpenditure.htm (Erişim Tarihi:03.01.2018) 
Grafik 3. Norveç'de Sosyal Harcamaların Amaçlarına Göre Dağımı (2016 Yılı)

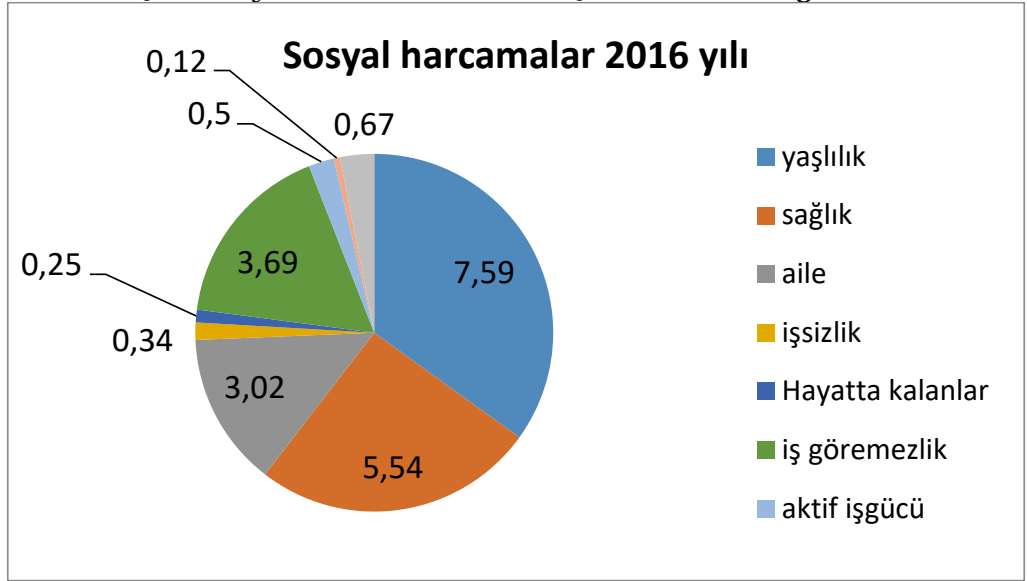

Kaynak: Tarafımızca hazırlanmıştır.

OECD'nin sosyal harcamalar tanımında nakdi ödemeler ve doğrudan ayni mal ve hizmetlerin sağlanması, sosyal amaçlı vergi muafiyet ve istisnalarını içermektedir. Bunlar, yaşlılık maaş ödemeleri, erken dönem emekli maşları, yaşlılara evde bakım hizmetleri, çocuk ve aile yardımları, çocuk bakım destekleri, gelir destekleri, işsizlik tazminatı, hayatta kalanlara yapılan emekli maaş ödemeleri, cenaze ödemeleri, iş göremezlik ödeneği, bakım hizmetleri, sakatlık yardımları, mesleki yaralanmalar, işçi hastalık ödemeleri, iş kazası ödemeleri, istihdam hizmetleri, eğitimi, istihdam teşvikleri, engellilerin istihdama yöneltilmesi, iş yeri açma teşvikleri, konut yardımları, kira sübvansiyonları, diğer teşvikler şeklindedir. Yapılan ödemeler düşük gelirli hanehalkına, yaşlılara, sakatlara, hastalara, işsiz ve gençlere yapılmaktadır. Gini katsayısı, Norveç 2015 yılında 0,27'dir birinci sirada Slovenya 0,25'dir.

Tablo 8 de görüldüğü üzere OECD'nin yayınlamış olduğu Daha İyi Yaşam Endeksini oluşturan 11 göstergeden Norveç 38 ülke içerisinde 7 göstergede ilk 10 içerisinde yer almaktadır. Hatta Konut, İs, Çevre, Yaşam memnuniyeti, Güven göstergelerinde ilk üçde yer almaktadır. Norveç'in tüm göstergeler açısından değerlendirildiğinde refah devleti açısından ileri seviyede olduğu görülmektedir.

Tablo 8. Norveç'in Daha İyi Yaşam Endeksi Göstergeleri 


\begin{tabular}{|c|c|c|c|c|c|c|}
\hline & Konut & Gelir & İş & Toplum & Eğitim & Çevre \\
\hline $\begin{array}{l}\text { Norveç } \quad\left(\begin{array}{ll}38 & \text { Ülke } \\
\text { sırası }\end{array}\right. \\
\end{array}$ & 2 & 16 & 3 & 7 & 14 & 2 \\
\hline Maksimum Puan & 8,7 & 10,0 & 9,5 & 10,0 & 8,7 & 10,0 \\
\hline Norveç'in Puanı & 8,6 & 4,3 & 8,7 & 8,1 & 7,1 & 9,4 \\
\hline Minimum Puan & 2,5 & 0,3 & 0,2 & 0,0 & 0,6 & 2,5 \\
\hline & $\begin{array}{c}\text { Sivil } \\
\text { Katılım }\end{array}$ & Sağlık & $\begin{array}{c}\text { Yaşam } \\
\text { Mem- } \\
\text { nuniyeti }\end{array}$ & Güven & $\begin{array}{c}\text { İş- } \\
\text { Yaşam } \\
\text { Dengesi }\end{array}$ & \\
\hline $\begin{array}{l}\begin{array}{l}\text { Norveç } \\
\text { sırası }\end{array} \\
(38 \text { Ülke }) \\
\end{array}$ & 14 & 9 & 1 & 1 & 6 & \\
\hline Maksimum Puan & 8,6 & 9,6 & 10,0 & 9,9 & 9,3 & \\
\hline Norveç'in Puanı & 5,6 & 8,8 & 10,0 & 9,9 & 8,5 & \\
\hline Minimum Puan & 1,3 & 3,1 & 0,0 & 0,1 & 0,0 & \\
\hline
\end{tabular}

Kaynak:http://www.oecdbetterlifeindex.org/\#/11111111111(ErişimTarihi:22.01.2018).

Norveç 2017 yılı Legatum Prosperty İndeksine göre 149 ülke arasında birinci sırada yer almaktadır. Bu endeks 9 tane bileşenden oluşmaktadır, Norveç bu bileşenlerde puan sıralaması üst sıralardadır, doğal çevre bileşeninde 1. Sıradadır. 2016 yılında yapılan ankete göre yaşam standartlarından memnun musunuz sorusuna dünya ortalaması \%60 evet derken, Norveç'de yaşayanlar \%93'ü evet demiştir (Legatum Prosperity Index 2016 Norway). Bu da Norveç'de yaşayanların yaşam kalitesinin yüksek olduğunun bir göstergesidir. Ayrıca dünya ortalamasının çok üstünde bir memnuniyet durumu vardır.

Tablo 9. Norveç'in 2017 Legatum Prosperty İndeksine Göre 149 Ülke İçerisindeki Stralamast

\begin{tabular}{cc}
\hline BİLEŞEN & SIRALAMA \\
\hline Ekonomik Kalite & 8 \\
\hline İş̧ Çevresi & 8 \\
\hline Hükümet-Yönetim & 2 \\
\hline Eğitim & 4 \\
\hline Sağllk & 7 \\
\hline Güven-Güvenlik & 3 \\
\hline Kişisel Özgürlük & 8 \\
\hline Sosyal Sermaye & 5 \\
\hline Doğal çevre & 1 \\
\hline
\end{tabular}

Kaynak: http://www.prosperity.com/globe/Norway, (Erişim Tarihi:23.01.2018) 


\section{Norveç Refah Devleti Uygulaması Açısından Sunulan Hizmetler}

Hem refah kavramının içeriği hem de uygulamadaki tarihsel değişimi Norveç Refah Devleti modelini ilgi çekici bir konu yapmaktadır. Norveç refah devleti modelinin tarihsel değişimlere karşın kendine has çekirdek özellikleri vardır özellikle refah devletinin sosyal politikası kapsamlıdır, evrensel sosyal yasaları ve kurumsallaşmış sosyal hakları içerir (Jacobsen ve Mekki, 2012, s. 127).

Yerel yönetimler kreş, ilköğretim, koruyucu ve önleyici sağllk hizmetleri, sosyal hizmetler, sosyal destek, sığınmacı ve mülteciler için bütünleştirme çalışmalarını yerine getirmektedir. İl yönetimi orta öğretim okulları ve diş sağlığı hizmetlerinden sorumlu birimlerdir. Merkezi yönetim ise güvenlik, iş yerleri ve hastanelerden sorumludur. Belediye Sağlık Hizmetleri Kanunu zorunlu sağlık hizmetlerinden tüm vatandaşların yararlanabileceğini belirtir. Merkezi yönetim yaşlı ve engelli bireylerin mümkün olduğunca evlerinde hizmet almalarını desteklediği için yerel idarelerin evde bakım hizmetlerini vermesini desteklemektedir (Gülaldı, 2009, s. 5).

Norveç refah devleti sistemi yaşlılar, engelliler ve çocuklara öncelik vermesi ile tanımlanmaktadır. Tarihsel olarak bu hizmetler yerel idarelerinöncülüğünde yoksul ve muhtaç kişiler için yerine getirilmiştir. Norveç'de yaşlı bakım hizmetleri İsveç ve Danimarka'dan sonra gelişmeye başlamıştır. Şu anda çocuklarla ilgili hizmetlerde bu iki ülkeyi takip etmektedir. 1880-1920 yılları arasındaki yoksullar eviyerini yaşlı bakım evine bırakmıştır. 1960'lardan sonra ise huzurevleri yaygınlaşmıştır (Gülaldı, 2009, s. 5).

Norveç'de temel sosyal sigorta programı, Ulusal Sigorta Programı, Aile Ödenek Programı ve Küçük çocuklu Ailelere Yönelik Nakdi Yardım Programından oluşur ( The Norwegian Social Insurance Scheme, 2015). 
Grafik 4. Belediyelerin Sunmuş Oldukları Hizmetlerin Harcama Oranları (2014)

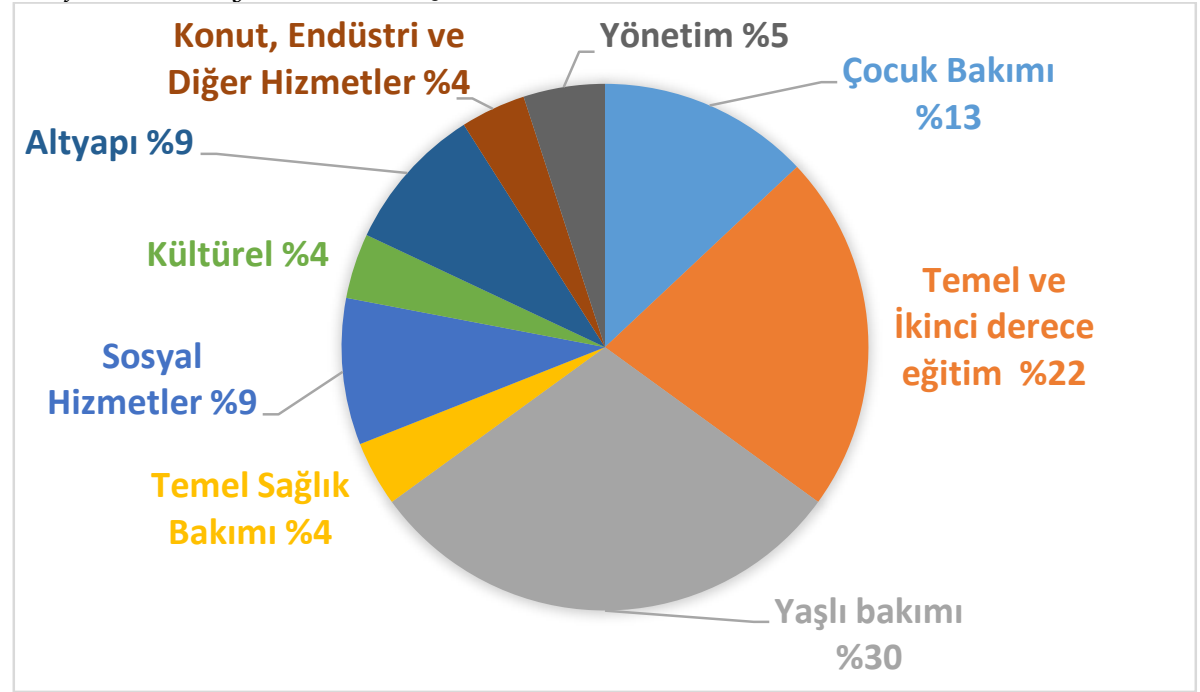

Kaynak: Lars-Erik Borge, 2016:3

Grafikte görüldüğü gibi, eğitim, sağlık ve sosyal hizmetler gibi refah hizmetleri harcamaların büyük bir kısmını oluşturmaktadır. Belediyelerin sunmuş olduğu refah hizmetleri, çocuk bakımı, temel ve ikincil eğitim hizmetleri, yaşlı bakım hizmetleri ve sosyal hizmetler (özellikle, sosyal yardım, madde bağımlılık tedavisi, işgücü eğitimi, çocuk bakımı). Bu hizmetler bütçenin dörtte üçünü oluşturmaktadır.

\section{Belediyelerin sorumlu olduklarn alanlar;}

İlkokul ve ikinci derece okul hizmetleri, çocuk yuvaları ve kreş hizmetleri, birinci basamak sağlık hizmetleri, yaşlı ve engelli bakım hizmetleri, yerel planlama, tarımsal konular, çevre sorunları, yolların yapımı, limanlar, su kaynağı ve temizliği, kanalizasyon hizmetleri (Local Government in Norway, 2014, s. 11).

Belediyeler tarafindan sunulan refah yardımları ve hizmetleri yerel vergiler ile merkezi hükümet tarafından aktarılan bağışlarla finanse edilir (Schafft, 2009, s. 1). 
Grafik 5. İl Yönetiminin Sunmuş Oldukları Hizmetler, Harcamaların \%'si 2014 Yılı

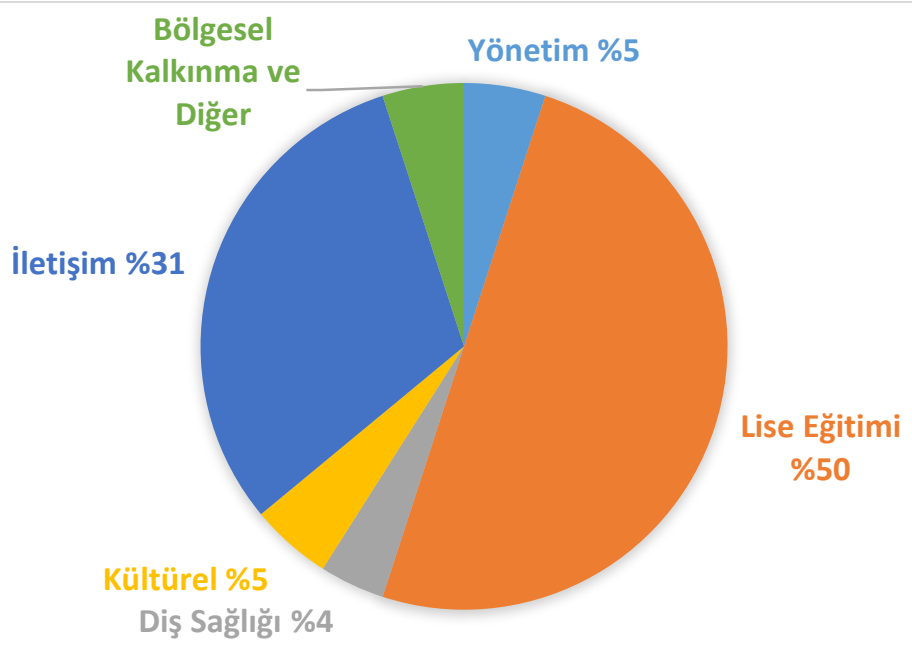

Kaynak: Lars, 2016,s.3

İl yönetiminin en önemli görevi, üst düzey eğitim hizmetlerini sağlamaktır. Toplam bütçelerinin yarısını oluşturmaktadır. Diğer önemli harcama kalemi ise ulaşım hizmetleri (yol ve kamu ulaşım hizmetleri) bütçenin dörtte birini oluşturmaktadır. Diğer hizmetler ise diş sağlığı hizmetleri, kültürel hizmetler, bölgesel kalkınmadır.

İl yönetiminin sorumlulukları; üst düzey okul hizmetleri, bölgesel kalkınma, yol bakım hizmetleri, toplu taşıma, bölgesel planlama, kültürel hizmetler, kültürel miras, çevresel meseleler (Local Government in Norway, 2014, s. 10).

\subsection{Yaşlılara yönelik hizmetler}

Norveç'in diğer Avrupa ülkelerinde olduğu gibi nüfusu yaşlanmaktadır. Norveç'de ülkeye net göç girişi olmakta ve doğum oranı yüksek olduğundan nüfusun yaşlanması sorununu nispeten hafifletmektedir (National Report on Ageing, 2016). Norveç'de 67 yaş ve üzerindeki nüfus 2017 yılında 766002 kişidir ve toplam nüfusa oranı \% 14,6'dır. (https://www.- 
ssb.no/en/befolkning/statistikker/folkemengde/aar-per-1-januar, Erişim tarihi: 16.11.2017).

Norveç'de tüm yaşlı insanlar emeklilik maaşı alırlar. Bu emeklilik maaşı son gelire göre değişir. Norveç'de çoğu yaşlı insan kendi evinde yaşar. Bazıları belediyelerden yardım alır, çoğu kişi kendi kendine ya da aile fertlerince yardım sağlanır. Yaşlı insanlar kendilerine bakamayacak duruma geldiklerinde bir bakım evine götürülür fakat bakım evine gidenler çoğunlukla 90 yaş üstü kişilerdir. (http://www.samfunnskunnskap.no/?page id=521\&lang=en, Erişim tarihi: 16.11.2017 ).

Tablo 10. Norveç'de Yaşlı Nüfusun Toplam Nüfusa Oranı (65 Yaş ve Üzeri Nüfusun Toplam Nüfusa Orani)

\begin{tabular}{lllllll}
\hline Y1llar & $\mathbf{1 9 7 0}$ & $\mathbf{1 9 8 0}$ & $\mathbf{1 9 9 0}$ & $\mathbf{2 0 0 0}$ & $\mathbf{2 0 1 0}$ & $\mathbf{2 0 1 4}$ \\
\hline Norveç & 12,89 & 14,76 & 16,32 & 15,16 & 14,97 & 16,02 \\
\hline Avrupa & 11,46 & 13,16 & 13,68 & 15,57 & 17,52 & 18,37 \\
$\begin{array}{l}\text { Birliği } \\
\text { (28 Ülke) }\end{array}$ & & & & & & $(2013)$ \\
\hline
\end{tabular}

Kaynak: OECD Data, Elderly Population, https://data.oecd.org/pop/elderly-population.htm, (Erişim Tarihi: 23.01.2018).

Norveç'de Belediye yaşlı bakım hizmetleri Sosyal Demokrat ya da İskandinav refah devleti modeli denilen versiyonun önemli bir parçası olarak düşünülür. (Jacobsen ve Mekki, 2012, s. 127).

Norveç'te yaşlı nüfusun yaklaşık beşte ikisi evde bakım ve destek hizmetleri bakım sigortası kapsamındadır. İskandinav ülkelerinde nüfusun tamamı sosyal güvenlik sistemi kapsamındadır, bu nüfus grubunun yarısina yakını, sosyal bakım odaklı toplum temelli sosyal hizmetlerden yararlanmaktadır. Yaygın bir şekilde bulunan gündüzlü bakım merkezleri aracılığı ile yaşlıların durumu yakından takip edilmekte olup, acil durumlara karşı yaşlıların güvenliğini sağlamak için gerekli tedbirler alınmaktadir (Albayrak ve Birinci, 2017, s. 80).

"Belediye Sağlık Hizmetleri Yasası" yerel idareleri halk sağlığı ve refahını arttırmak, iyi bir sosyal ve çevresel şartları oluşturmak, hastalık ve kazalara karşı önleyici önlemleri almakla sorumlu tutmaktadır (Gülaldı, 2009, s. 5). 


\subsection{Sağlık Hizmetleri}

Norveç'de yaşayan tüm vatandaşların zorunlu sosyal güvenlik kapsamında olup ülkenin sağlık sisteminin birçok alanında kamu sağlık sistemi ağırlıklıdır ve sağlık hizmetleri ağırlıklı olarakdevlet tarafından karşılanmaktadır. Devlet sağlıkla ilgili hizmetlerin kalitesinden tüm sistemin kapasitesinin belirlenmesinden ve sağlık politikalarından sorumludur. Tüm ülkenin sağlık politikalarının belirlenmesinden sorumludur. Yerel demokrasiye uygun olarak sağlık hizmetleri yerel yönetimlerce sunulmaktadır.

Norveç'de sağlık hizmetleri çoğunlukla sosyal güvenlik kapsamındadır. Merkez ve yerel yönetimlerin vergileri ile sağlık hizmetlerinin finansmanı karşılanmaktadır. Sosyal sigorta primleri vergilere göre daha düşük kalmaktadır (Sargutan vd., 2064).

Refah devleti ile ilgili çalışmalarda, bir ülkenin diğer tüm ülkeleri hiç dikkate almadan kendi refah devletini oluşturması ve buna bağlı olarak sağlık politikası uygulaması mümkün değildir. Aynı coğrafyayı paylaşan ülkeler, diğer ülkedeki refah devleti uygulamalarından etkilenmektedir (Günaydın, 2011, s. 46).

Tablo 11: Norveç'de Sağlık Harcamalarının GSYH'ya Oranı \%

\begin{tabular}{llllllllll}
\hline Yillar & $\mathbf{2 0 0 0}$ & $\mathbf{2 0 0 1}$ & $\mathbf{2 0 0 2}$ & $\mathbf{2 0 0 3}$ & $\mathbf{2 0 0 4}$ & $\mathbf{2 0 0 5}$ & $\mathbf{2 0 0 6}$ & $\mathbf{2 0 0 7}$ & $\mathbf{2 0 0 8}$ \\
\hline $\begin{array}{l}\text { Sağlık } \\
\text { H./gsyh }\end{array}$ & 7,7 & 8,0 & 9,0 & 9,2 & 8,8 & 8,3 & 7,9 & 8,1 & 8,0 \\
\hline $\begin{array}{l}\text { Yillar } \\
2009\end{array}$ & 2010 & 2011 & 2012 & 2013 & 2014 & 2015 & 2016 & \\
\hline $\begin{array}{l}\text { Sağlık } \\
\text { H./gsyh }\end{array}$ & 9,1 & 8,9 & 8,8 & 8,8 & 8,9 & 9,3 & 10,0 & 10,5 & \\
\hline
\end{tabular}

Kaynak: OECD, Health spendinghttps://data.oecd.org/healthres/health-spending.htm, (Erişim Tarihi:16.11.2017)

\section{3. İstihdama Yönelik Hizmetler ve İşsizlik Hizmetleri}

Merkez hükümet genel işgücü piyasasına yönelik politikalardan ve istihdama karşı zayıf grupları işgücü piyasasına dahil etme açısından 
sorumludur. Hükümet ayrıca sosyal sigorta ve aile yardımlarının bazılarından sorumludur. Belediyeler temel sağlık hizmetleri çocukların günlük bakımı temel ve daha düşük ikincil düzeydeki okullardan, yaşlı ve engelli bakımı, sosyal hizmetler ve sosyal yardım ödemelerinden sorumludur (Schafft, 2009, s. 2).

Ülkeler arasında pek çok sosyo-ekonomik göstergeye göre karşılaştırma imkânı veren Avrupa Nüfus Çalışmaları Kurumunun hazırladığı Karşılaştırmalı Aile Politikaları Veri Tabanı (Comparative Family Policy Database-CFPD) verilerine göre 2008 itibarıla Lüksemburg ve İsviçre'den sonra işgücüne katılım oranı en yüksek olan ülke Norveç'tir. İstihdam edilen nüfusun \%30'u kamu kesiminde ve yüksek eğitimli işgücü çoğunlukla kamu kesiminde çalışmaktadır (Karahanoğulları, 2013, s.236-237).

Norveç'te aktif ve pasif istihdama yönelik politikalara göre çalışan bireylerin işsizlik sigortasına katkıda bulunmaları gerek yoktur. İşsizliğe yönelik ödemelerin vergi gelirlerinden karşılanması uygulanmakta olan işsizlik politikalarına esnekliğini arttırmaktadır. Norveç'te, pasif istihdam politikası niteliğindeki işsizlik sigortasının yanı sıra birey ve şirket bazlı olmak üzere uygulanan aktif istihdam politikaları da bulunmaktadır. Norveç işsizlikle ilgili olarak daha çok işgücünün eğitime önem vermektedir (Albayrak ve Birinci, 2017, s.75).

Norveç kadın işgücünün artmasına yönelik unsurlardan biri de yerel idarelerin çocuklara yönelik kreşlerin olması, sağlık ve sosyal hizmetler alanlarında yaptığı imkanlar istihdamı arttırmıştır (Karahanoğulları, 2013, s.236-237).

Norveç ekonomisinin diğer bir özelliği de, yarı zamanlı istihdam oranının yüksek olmasıdır. Norveç'in ortalama kişi başına haftalık çalışma saati diğer gelişmiş ülkelere göre oldukça düşük kalmaktadır. Bunun sebebi de yarı zamanlı çalışan kadın ve genç nüfusun işgücüne katılım oranının yüksek olmasındandır. Kişi başına milli gelirin bu kadar yüksek olduğu bir ülkede, ortalama çalışma süresinin nispi olarak düşük olması kişilerin toplumsal zenginlikten yeterince pay alarak zamanlarının daha büyük bir kısmını çalışma dışı faaliyetlere yönelme isteğinin ve fırsatının olduğunun bir göstergesi olarak da yani bir toplumsal refahın da göstergesi olarak değerlendirilebilir (Karahanoğulları, 2013, s.236-237). 
Tablo 12. Norveç'de İstihdam Oranı

\begin{tabular}{ccccc}
\hline Yillar & $\mathbf{2 0 0 0}$ & $\mathbf{2 0 0 5}$ & $\mathbf{2 0 1 0}$ & $\mathbf{2 0 1 5}$ \\
\hline Kadın & 73,65 & 71,75 & 73,25 & 72,95 \\
\hline Erkek & 81,30 & 77,85 & 77,25 & 76,53 \\
\hline Toplam & 77,50 & 74,83 & 75,30 & 74,80 \\
\hline
\end{tabular}

Kaynak:Employment rateTotal, \% of working age population, 2000 - 2015,

https://data.oecd.org/emp/employment-rate.htm, (Erişim Tarihi: 16.01.2018).

Norveç diğer ülkelerle karşılaştırıldığında istihdam oranı her iki cinsiyet için de yüksektir ve işsizlik oranı düşüktür.

\subsection{Aile Kadın ve Çocuklara Yönelik Hizmetler}

Norveç diğer sanayileşmiş ülkelere göre nispeten istihdamda kadınların oranı yüksektir ve doğum oranı da nispeten yüksektir. Bireylerin çocuk sahibi olmalarında kamu politikaları etkilidir.

\subsection{Eğitime Yönelik Hizmetler}

Norveç'te kadınlar genellikle bir yerlerde çalışmış olduklarından ev hanımı olan kadın sayısı çok azdır. Tam zamanlı çalışma yanı sıra esnek zamanlı çalışmanın da olması Norveç'teki her kadının bir işinin olması veya aktif olarak iş aramaktadırlar. Bu sebeple çocuk kreşlerinin en çok olduğu ülkelerin başında Norveç gelir. İlkokul çağının ilk dört yılında okul sonrası çocuklara ücretli bakım ve etüt sağlanır. Varolan bu sistem ile anne ve baba aktif olarak çalışabilir (Alan, 2015, s.15). Yuvaların çoğunluğu kamuya aittir. Kamu yuva parasının bir kısmını karşılar, çocuk henüz yuvaya başlamamışsa bu para doğrudan aileye ödenir. Norveç'te okul, ders kitapları, ilkokul çantası, kırtasiye, kütüphaneler, sağlık hizmetlerinin hepsi devlet tarafından karşılanır. Bunların dışındaki ihtiyaçlar için diğer çocuklarla aynı oranda karşılayamayan çocukların ailelerine devlet ayrıca maddi destek de bulunur. Örneğin her çocuğun yaşına uygun bir bisikleti olmalıdır (Alan, 2015: 15). 
Tablo 13. Sosyal Harcamalarn GSYH'ya Oranı \%

\begin{tabular}{lccccccccccc}
\hline Yıllar & $\mathbf{1 9 8 0}$ & $\mathbf{1 9 8 5}$ & $\mathbf{1 9 9 0}$ & $\mathbf{1 9 9 5}$ & $\mathbf{2 0 0 0}$ & $\mathbf{2 0 0 5}$ & $\mathbf{2 0 1 0}$ & $\mathbf{2 0 1 3}$ & $\mathbf{2 0 1 4}$ & $\mathbf{2 0 1 5}$ & $\mathbf{2 0 1 6}$ \\
\hline $\begin{array}{l}\text { Sosyal } \\
\begin{array}{l}\text { Harcama- } \\
\text { larin }\end{array}\end{array}$ & 16,1 & 17,2 & 21,6 & 22,5 & 20,4 & 20,7 & 21,9 & 21,8 & 22,4 & 23,9 & 25,1 \\
$\begin{array}{l}\text { GSYH'ya } \\
\text { Oranı }\end{array}$ & & & & & & & & & & & \\
\hline
\end{tabular}

Kaynak: OECD, Social spending

https://data.oecd.org/socialexp/social-spending.htm (Erişim Tarihi:16.11.2017).

\section{Refah Hizmetlerinin Finansmanı}

Gelişmiş ülkelerde refah devleti hizmetlerine olan talep artışı yurtiçi sosyal harcamaların oranını OECD ülkelerinde ortalama olarak 1960' da $\% 7$ iken 2007 'de \%19'lara yükseltmiştir. Avrupa Birliğinde bu harcamalar \%26'lara ulaşmıştır(Morel ve Palme, 2012, s. 1)

Refah hizmetleri ve sosyal yardım ödemeleri belediyelerce karşılanır ve özellikle yerel vergiler ve belediyelere aktarılan fonlarla finanse edilir (Schafft, 2009, s. 2). Sosyal sigorta ödemelerinin finansmanı işveren katkıları kendi hesabına çalışanların katkıları, çalışanların katkıları ve devlet katkısından oluşur. Devlet katkılarına parlamento karar verir. Çalışanların katkısı brüt ücretin \%8,2'dir. İşveren katkısı \%0-14,1 arasında değişmektedir. Ulusal sigorta programının 2014 y1lında toplam harcama tutarı Norveç bütçesinin \%35,3'ünü, GSYH'nin \%12,4'ünü oluşturmaktadır. Ulusal sigorta programını \%26,1'ini devlet finanse eder. Aile yardımları, küçük çocuklu ailelere nakdi yardım ödemeleri devlet bütçesinden karş1lanmaktadır (The Norwegian SocialInsurance Scheme, 2015, s. 5-6).

Tablo 14. Norveç Vergi Gelirlerinin GSYH'ya Oranı \%

\begin{tabular}{llllllllll}
\hline Yillar & $\mathbf{1 9 7 5}$ & $\mathbf{1 9 8 0}$ & $\mathbf{1 9 8 5}$ & $\mathbf{1 9 9 0}$ & $\mathbf{1 9 9 5}$ & $\mathbf{2 0 0 0}$ & $\mathbf{2 0 0 5}$ & $\mathbf{2 0 1 0}$ & $\mathbf{2 0 1 5}$ \\
\hline Vergi & 20,38 & 25,11 & 25,65 & 21,30 & 23,46 & 26,78 & 28,19 & 26,85 & 22,44 \\
G./GSYH & & & & & & & & &
\end{tabular}

Kaynak: World Bank Data Tax Revenue Statistic, https://data.worldbank.org/indicator/GC.TAX.TOTL.GD.ZS?locations=NO (Erişim Tarihi:16.11.2017 


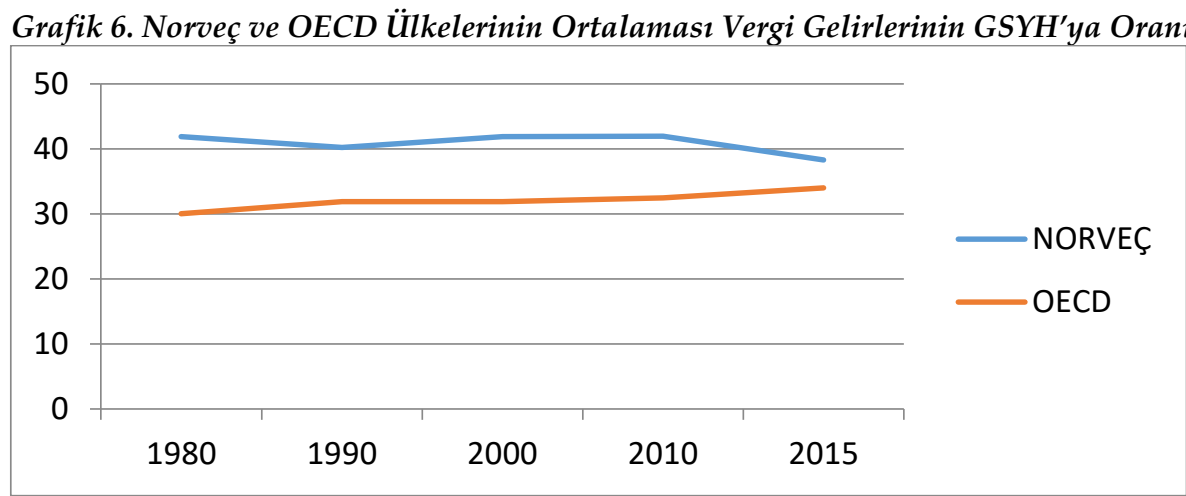

Kaynak: Tarafımızca hazırlanmıştır.

Tablo 15. Norveç'in Kamu Gelirlerinin GSYH'ya Oranı \%

\begin{tabular}{cccccc}
\hline Yillar & $\mathbf{1 9 9 5}$ & $\mathbf{2 0 0 0}$ & $\mathbf{2 0 0 5}$ & $\mathbf{2 0 1 0}$ & $\mathbf{2 0 1 5}$ \\
\hline Kamu Gelirleri/GSYH & 54,03 & 57,14 & 56,88 & 55,94 & 54,77 \\
\hline
\end{tabular}

Kaynak: OECD, General Government Revenue, https://data.oecd.org/gga/general-government-revenue.htm\#indicator-chart. (Erişim Tarihi:16.11.2017).

Tablo 16. Norveç Kamu Borç Stoku GSYH'ya Oranı \%

\begin{tabular}{cccccc}
\hline Yillar & $\mathbf{1 9 9 5}$ & $\mathbf{2 0 0 0}$ & $\mathbf{2 0 0 5}$ & $\mathbf{2 0 1 0}$ & $\mathbf{2 0 1 5}$ \\
\hline Borç/stoku/GSYH & 37,3 & 32,2 & 46,9 & 48,4 & 38,6 \\
\hline
\end{tabular}

Kaynak: OECD General government debt, https://data.oecd.org/gga/general-government-debt.htm. (Erişim Tarihi:16.11.2017).

\section{Sonuç}

Norveç'de 1945-1965 dönemde ekonomik büyüme ve tam istihdam o dönemin hükümetlerinin ana amaçlarındandır. 1940'larda ve 1950'lerin başlarında hükümetlerin gündemlerinde ilk başta ekonomik büyüme daha sonra bölüşüm yer almaktaydı. 1966'da Parlamento çeşitli kamu emekli ödemelerini ulusal sigorta programı kapsamına almıştır. 1970'lerde yaşanan petrol krizi ve dünya ekonomisinin gerilemesi refah hizmetlerinde ve ödemeleriyle ilgili devlet harcamalarında başlangıçta bir düşüş olmamıştır. Norveç refah devleti anlayışında dikkate değer değişmeler olmasına karşın refah devletinin çekirdek alanlarını oluşturan sağlık, eğitim ve emekli maaş ödemeleri gibi harcamalar 1980'den sonra artmaya devam etmektedir. Norveç'in 2016 yılı kişi başına gayri safi yurt 
içi hasılası 62.152 dolardır bu birçok Avrupa ülkesinden ve diğer OECD ülkelerine göre yüksek bir rakamdır.

Norveç küçük nüfuslu fakat yüzölçümü bakımından büyük bir ülkedir. 1960'ların sonlarına doğru petrol ve gaz kaynaklarının bulunmasıyla buradan elde edilen geliri etkili bir şekilde kullanarak refah devletinin gerektirdiği hizmetlere kaynak sağlamıştır. Günümüz açısından birçok refah göstergesinde en yüksek sıralarda yer almaktadır. Bu başarısını sağlamada yönetim kalitesi büyük rol oynamaktadır. Bir partinin parlamentoda temsiliyle yönetilmektedir ve birçok konuda partiler arası uzlaşmanın yüksek olduğu görülmektedir.

Kamu sektörünün ağırlıklı olmasına rağmen bu özel sektör açısında bir engel değil özel sektörün bir tamamlayıcısıdır. Hükümet kamu kaynaklarını en iyi şekilde kullanarak vatandaşına birçok alanda refah hizmeti sunmaktadır. Bunda tabikide doğal kaynakların rolü yadsınamaz. Birçok alanda çalışan işveren arasında uzlaşmanın olması, devletin işgücü piyasana aktif olarak destek vermesi, Norveç'in istihdama katılım oranını yükseltmekte ve işsizlik oranını çok düşük düzeylere indirmektedir.

Devletin amacı insanlara pasif ödeme şeklinde yardım etmek şeklinde değilde çalışma gücü olan kişileri istihdama yönelterek onlara aktif destek sağlamaktadır. Kamu refah hizmetlerini sunmada yerel yönetimlere birçok alanda yetkiler vermiş ve bu hizmetleri sağlaması için de kaynak aktarmıştır. Norveç kadınların istihdama yönelmesini kolaylaştıracak birçok desteğinide sağlamaktadır. Çocuk bakım evleri, esnek çalı̧̧ma şartları, ücretsiz izin gibi kolaylaştırıcı politikalar uygulamaktadır.

Refah devletinin göstergelerinden birisi olan kamu sosyal harcamalarının GSYH'ya oranı açısından Norveç OECD ortalamasının üzerindedir ve yıllar itibariyle bu oran yükselmiştir. 2016 yılında bu oran \%25,1 olarak gerçekleşmiştir. Norveç nüfus olarak diğer ülkelerde olduğu gibi nüfusu yaşlanmaktadır bunu önlemeye yönelik çeşitli politikalar uygulamaktadır bunlar kadınların doğum yapmasını desteklemeye yönelik politikalar ve net göç politikaları uygulamaktadır. Nüfusun yaşlanması emekli maaş ödemelerini artırmaktadır refah devletinin sunmuş olduğu hizmetlerde biriside emekli maaş ödemeleridir. Yıllar itibariyle bütçe üzerinde yükü artmaktadır. 
EXTENDED ABSTRACT

\title{
Show Up and Development of The Welfare State in Norway
}

\author{
* \\ Mahmut Küçükoğlu - Hüseyin Ercan \\ Yalova University - Harran University
}

Norway is generally known as a good representative of the social state and the democratic welfare state. When compared with other developed countries in the world, it is seen that the level of injustice and poverty in the income distribution is low, and that high level of social trust and quality of living standards are established. The Norwegian welfare state has three characteristic features, first, a comprehensive social policy, second, institutionalized social rights, the third is solidarity and universal social laws. The Norwegian welfare state model is responsible for providing income security and welfare services to all citizens living in the country. Education, health, elderly and disabled care services are covered by the public. A universal and generous social security system is based on individual rights and obligations. The main feature of the Norwegian welfare state is the unification of the labor market and the welfare system. The management and financing of the welfare state is shared between the central government and the local government. In this study, based on the definition and historical development of the concept of welfare state, the example of Norway will be discussed and the basic features of the Norwegian welfare state and some other developed countries, social policies and public revenues and expenditures will be compared and the basic elements of the welfare state will be discussed.

In Norway, economic growth and full employment in 1945-1965 were the main objectives of the governments of that period. In the 1940s and early 1950s, governments' agendas were initially followed by economic growth and then the distribution took place. Despite significant changes in the Norwegian welfare state concept, expenditures such as health, ed- 
ucation and pension payments, which constitute the core areas of the welfare state, continue to increase after 1980. Norway's GDP per capita in 2016 is $\$ 62.152$, a high figure compared to many other European countries and other OECD countries. Norway has a small population but is a large country in terms of area. Nowadays, it is at the highest rank in terms of many welfare indicators. Management quality plays a major role in achieving this success.

It is governed by the representation of a party in parliament and it is seen that there is a high level of agreement among parties on many issues. Although the public sector is predominant, this is not a barrier to the private sector, but a complement to the private sector. The government uses its public resources in the best way and offers its citizens welfare services in many areas. Naturally, the role of natural resources in this can not be denied. Compromise between workers and employers in many areas, active support of the state in the labor market, It increases Norway's participation in employment and thus the unemployment rate is very low. The aim of the state is not to help people in the form of passive payment, but to provide them with active support by directing people with working power to employment. State gave authorities in many areas to provide public welfare services and provided resources to provide these services. Norway provides a lot of support to facilitate women's orientation towards employment.

It implements facilitative policies such as child care homes, flexible working conditions and free leave. Public social spending, which is one of the indicators of welfare state In terms of GDP ratio, Norway is above the OECD average, and this ratio has increased by years. In 2016, this rate was $25.1 \%$. The population of Norway is aging as in other countries, implements various policies to prevent this, policies to support women to give birth and implements clear migration policies. Aging of the population increases pension payments. One of the services provided by the welfare state is the pension payments. Over the years the burden on the budget is increasing. The welfare services and social assistance payments are covered by the municipalities and are financed mainly by local taxes and funds transferred to municipalities.

Compared to other industrialized countries, Norway is relatively high in female employment. Another feature of the Norwegian economy is the 
high rate of part-time employment. Social protection expenditures have the highest share in the distribution of public expenditures according to their functions.One of the aims of the welfare state is to distribute risks such as aging, unemployment and illness.When we look at the ratio of public social expenditures to GDP, it increased to $25 \%$ in 2016 while it was $20 \%$ in years. When we look at the content of social expenditures, the highest rate is paid pension payments to the elderly. Health-related transfer expenditures are the second. Public pension payments and health care expenditures constitute $60 \%$ of public social expenditures.

\section{Kaynakça / References}

Akkaya, Y. (2001). Refah devletinden asgari geçim devletine. Erişim Tarihi: 10.01.2018. Erişim Adresi: http://e-kutuphane.teb.org.tr/pdf/toplumsaglik-eczaci/Tem_Ara01/5.Pdf

Albayrak, T., E. ve Birinci, M. (2017). Sosyal devlet modelleri: Sosyal demokrat model, İsveç-Norveç örneği. Journal Of Social Work,1(1), 64100.

Bjørnson O., (2010). The social democrats and the Norwegian welfare state: Some Perspectives. Scandinavian journal of history, 197-223. Http://Www.Tandfonline.Com/Doi/Abs/10.1080/03468750175030 3855 Erişim Tarihi: 15.01.2018.

Brigss, A.(1961). The welfare state in historical perspective. Erişim Tarihi: 10.01.2018. Erişim Adresi: Https://Www.Researchgate.Net/Publication/231854431_The_Welfare_State_In_Historical_Perspective.

Çiçek, H. G. ve Çiçek, S.(2012). Norveç yerel vergi sistemi. Uluslararası Yönetim İktisat Ve İşletme Dergisi, 8(16), 201-222.

Dahl, E. Vd. (2001). Norway: Relevance of the social development model for post-war welfare policy. International Journal Of Social Welfare, 10, 300-308.

Dikmen, S. (2015). Norveç'te kamu harcamalarının ekonomik analizi: 2000-2013, Dokuz Eylül Üniversitesi İktisadi Ve İdari Bilimler Fakültesi Dergisi, 30(2),189-214.

Erdal, S. (2012). Küreselleşme sürecinde refah devleti açısından Isveç modelinin değerlendirilmesi. Yayınlanmamış Doktora Tezi, Dokuz Eylül Üniversitesi Sosyal Bilimler Enstitüsü, İzmir. 
Fagerberg, J., Cappelen A., Mjoset, L. ve Skarstein, R., (1990). The decline of social-democratic state capitalism in Norway. New Left Review, 181, 60-94.

Greve, B. (2012). The routledge handbook of the welfare state, Routledge, Gülaldi, D. (2009). Uluslararası dostluk konseyi / cif, council of international fellowship, cif norveç mesleki ve kültürel değişim programı 2009 raporu (18 Nisan 2009 - 19 Mayıs 2009), Erişim Adresi: http://www.cifturkey.org/raporlar/GU_Isvec_2009.pdf

Günaydin, D. (2011). Küreselleşmenin refah devleti sağlık politikalarma etkileri: Türkiye örneği. Yayınlanmamış Doktora Tezi, Marmara Üniversitesi Sosyal Bilimler Enstitüsü, İstanbul.

Jacobsen, Frode F. ve Mekki, T. E. (2012). Health and the changing welfare state in Norway: A focus on municipal health care for elderly sick. Ageing International , 37(2), 125-142.

Karahanoğullari, Y. (2013). Norveç ekonomisine ve kamu maliyesine genel bir bakış. Maliye Dergisi, 164, 233-258.

Lars, E. B., (2016). Welfare services in Norwegian local governmnents: has decentralization come to an end?. http://www.Svt.Ntnu.No/Iso/Lars.Borge/Paper\%20leb\%20copenhagen\%202015\%20final\%20version.Pdf , (Erişim Tarihi: 11.01.2018)

Local Government In Norway (2014). Norwegian ministry of local government and modernisation public institutions may order additional copies from: Norwegian government administration services,(2014), Erişim Adresi: Http://Www.Mddsz.Gov.Si/Fileadmin/Mddsz.Gov.Si/Pageuploads/Dokumenti_Pdf/Enake_Moznosti/Nfmstudijski2lokalnoupravljanje.Pdf (Erişim Tarihi: 15.01.2018).

Morel, N. ve Palme J. (2013). Financing the welfare state and the politics of taxation. Norveç, population and population changes, Erişim Adresi: https://www.Ssb.No/En/Befolkning/Statistikker/Folkemengde/Aar-Per-1-Januar, Erişim Tarihi: 16.11.2017.

OECD Better Life Index, Erişim Adresi: Http://Www.Oecdbetterlifeindex.Org/\#/11111111111 Erişim Tarihi: 19.01.2018.

OECD DATA Elderly Population, Erişim Adresi: https://Data.Oecd.Org/Pop/Elderly-Population.Htm, Erişim Tarihi: 10.01.2018. 
OECD DATATAX Revenue, Erişim Adresi: Https://Data.Oecd.Org/Tax/Tax-Revenue.Htm, Erişim Tarihi: 18.01.2018.

OECD Economic Surveys: Norway (2016). https://doi.org$/ 10.1787 / 19990383$

OECD General Government Debt, Https://Data.Oecd.Org/Gga/GeneralGovernment-Debt.Htm. (Erişim Tarihi:16.11.2017).

OECD, Employment Rate Total, \% Of Working Age Population, Https://Data.Oecd.Org/Emp/Employment-Rate.Htm, Erişim Tarihi:16.11.2017.

OECD, General Government Revenue, Https://Data.Oecd.Org/Gga/General-Government-Revenue.Htm\#Indicator-Chart . Erişim Tarihi:16.11.2017.

OECD, Social Spending, Https://Data.Oecd.Org/Socialexp/Social-Spending.Htm Erişim Tarihi:16.11.2017.

Özdemir, S. (2007). Küreselleşme sürecinde refah devleti. İstanbul: İstanbul Ticaret Odası Yayını.

Özey, R. (2009). Avrupa coğrafyası. İstanbul: Aktif Yayınevi.

Royal Norwegian Ministry Of Labour And Social Affairs November 2016 Unece National Report On Ageing, (2016) - Norway.

Samfunnskunnskap.No, The Topics,Health, The Elderly And Health Care: "The Elderly And Health Care". Erişim Tarihi: 16.11.2017 http://www.samfunnskunnskap.no/?page_id=521\&lang=en

Sargutan, A. E. (2005). Sağlık sektörü ve sağlık sistemlerinin yapısı. Hacettepe Sağllk İdaresi Dergisi, 8 (3), 400-428.

Schafft, A. (2009). Developing well-targeted tools for the active inclusion of vulnerable people, Norway. The National Qualification Programm, Work Research Institute, Erişim Adresi: File:///C:/Users/Erc2/Downloads/Host\%20country\%20report_No\%2009\%20(1).Pdf, Erişim Tarihi: 10.01.2018.

Schafft, A. (2009). The national qualification programme work research institute 29-30 October peer review developing well-targeted tools for the active inclusion of vulnerable people, Norway.

Sørvoll, J. (2015). The Norwegian welfare state 2005-2015: Public attitudes, political debates and future challenges. https://Blogs.Kent.Ac.Uk/Welfsoc/Files/2015/05/S\%C3\%B8rvoll-2015-Norface-NwelfareState.Docx.Pdf (Erişim Tarihi: 10.01.2018). 
Stamsø, M.A. (2009). Housing and the welfare state in Norway. Scandinavian Political Studies, 32(2), 195-220. Doi: 10.1111/J.14679477.2008.00223.X.

Sven E., Hort O., Alestalo M., ve Kuhnle S.,(2009). The nordic model: Conditions, origins, outcomes, lessons. Http://Edoc.Vifapol.De/Opus/Volltexte/2013/4255/Pdf/41.Pdf, Erişim Tarihi: 10.01.2018.

Tatari, B. (2006). Norveç'in ticari ve ekonomik yapısı ve Türkiye Norveç ticari ve ekonomik ilişkileri.İzmir. Http://Www.Izto.Org.Tr/Portals/0/Iztogenel/Dokumanlar/Norvec_Rapor_4-17-2012.Pdf. Erişim Tarihi: 22.02.2016

The legatum prosperity index (2017), Erişim Adresi: Http://Prosperitysite.S3accelerate.Amazonaws.Com/3014/7861/2902/Norway.Pdf , Erişim Tarihi:16.11.2017.

The Norwegian Social Insurance Scheme, Norwegian Ministry Of Labour And Social Affair (2015),. Https://Www.Regjeringen.No/Globalassets/Departementene/Asd/Dokumenter/2015/A-0008-E_The-Norwegian-Social-İnsurance-Scheme_Web.Pdf Erişim: 15 Kasım 2017.

Worldbank data tax revenue statistic, Erişim Adresi: Https://Data.Worldbank.Org/Indicator/Gc.Tax.Totl.Gd.Zs?Locations=No_Erişimtarihi:16.11.2017.

Yıldırım, T. (2014). Refah devleti anlayışı: Tr33 bölgesinde eğitim, sağlık ve sosyo-ekonomik gelişmişlik düzeylerinin incelenmesi. Dumlupınar Üniversitesi Sosyal Bilimler Enstitüsü, Kütahya.

\section{Kaynakça Bilgisi / Citation Information}

Küçükoğlu, M. ve. Ercan, H. (2019). Norveç'te refah devletinin ortaya çıkışı ve gelişimi. OPUS-Uluslararası Toplum Araştırmaları Dergisi, 11(18), 2275-2308. DOI: 10.26466/opus.501680 